\title{
C. zeylanicum aqueous extract induced apoptosis in the human myelocytic leukemia cell line (THP-1)
}

\author{
Assadollahi V', Gholami $\mathrm{M}^{2}$, Zendedel $\mathrm{A}^{3}$ \\ Cellular and Molecular Research Center, Kurdistan University of Medical Sciences, Sanandaj, Iran. \\ anna.assadollahi@gmail.com
}

\begin{abstract}
Objective: The aim of this study was to evaluate the effect of $\mathrm{C}$. zeylanicum aqueous extract on cell growth in the human myelocytic leukemia cell line (THP-1).

Background: Today, application of Cinnamon for treatment of cancer investigates extensively. Cinnamon has antioxidant, anti-apoptotic and anti-inflammatory properties.

Methods: In this experimental study, THP-1 was incubated in 2, 1, 0.1 and $0.01 \mathrm{mg} / \mathrm{ml} \mathrm{C}$. zeylanicum solutions for 24,48 and 72 hours. Cell cycle was assessed with flow cytometry. Apoptotic cells were identified by Hoechst 33342 staining. Cell proliferation was assessed by the MTT assay. The data were analyzed using descriptive statistics and analytical tests.

Results: Samples that supplemented with $0.1 \mathrm{mg} / \mathrm{ml} \mathrm{C}$. zeylanicum aqueous extract enhanced induction of apoptosis in THP-1 cell line compared to samples that supplemented with 2,1 and $0.01 \mathrm{mg} / \mathrm{ml}$. According to flow cytometry analysis, after 24 and 72 hours of incubation in 0.1 and $2 \mathrm{mg} / \mathrm{ml} \mathrm{C}$. zeylanicum aqueous extract, respectively, the amount of cells in apoptosis phase was higher than that in the control sample.

Conclusion: Supplemented C. zeylanicum aqueous extract induced apoptosis in the human myelocytic leukemia cell line (Fig. 4, Ref. 20). Text in PDF www.elis.sk.

Key words: cinnamon, myelocytic leukemia cell, apoptosis.
\end{abstract}

\section{Introduction}

Leukemia and Lymphoma, among the different types of cancer, have a high importance with Global Outbreak 3-5 percent (1). Acute Myeloid Leukemia is hematopoietic cell neoplastic disorder caused by chromosomal abnormalities and mutations in blood precursor cells (2). The ability of cells to respond to signals that stimulate the differentiation and maturation are lost. High proliferation of early hematopoietic cells in the bone marrow and loss of differentiation into mature cells lead to a large accumulation of malignant cells in the bone marrow and ultimate in blood (3). Today, various therapies used to eliminate malignant cells in leukemia. Chemotherapy is a common method in the treatment of leukemia. Today, researcher investigated other types of treatment such as treatment with medicinal plant extracts due to severe side effects of chemotherapy (4). In recent years, researchers considered treatment with medicinal plant extracts. One of the strategies

${ }^{1}$ Cellular and Molecular Research Center, Kurdistan University of Medical Sciences, Sanandaj, Iran, ${ }^{2}$ Department of Anatomy, Faculty of Medicine, Lorestan University of Medical Sciences, Khoramabad, Iran, and ${ }^{3}$ Department of Internist, Faculty of Medicine, Lorestan University of Medical Sciences, Khorramabad, Iran

Address for correspondence: A. Zendedel, Department of Internist, Faculty of Medicine, Lorestan University of Medical Sciences, Khoramabad, Iran. Phone/Fax: +988716131376

Acknowledgement: This study approved in the Razi Herbal Medicines Research Center. Special thanks to Lorestan University of Medical sciences for the financial support. for treatments of cancer is prevent DNA synthesis or mitosis by blocking the progression of cell cycle in cells of the preneoplastic and malignant. Pharmaceutical plants have lethal impact on malignant or mutants cells by stopping the growth and proliferation (5).

Cinnamomum zeylanicum (C. zeylanicum) belongs to Lauraceae family and it grows in Srilanka. C. zeylanicum is an ancient medicinal plant. It has been mentioned in Chinese texts from 4000 years ago (6). In Ayurvedic medicine, cinnamon is suggested for the treatment of digestive, respiratory and gynecological disorders (7). It was reported that the cinnamon extracts could have antioxidant (8) and anti-inflammatory (9) effects. In diabetes-induced rats, C. zeylanicum recuperated lipid parameters and decreased blood glucose (7). Furthermore, chronic supplementation of cinnamon had improved the fasting glucose and lipid levels in diabetic patients (10). Also, it had been reported that cinnamon could affect the cell cycle. Researchers have shown that cinnamon induced loss of growth and apoptosis in cancer cell lines such as U937 and Jurkat, Cervical cancer SiHa and HL-60 (11-13). The aim of this study was to evaluate the effect of C. zeylanicum aqueous extract on the human myelocytic leukemia, THP-1, cell lines.

\section{Materials and methods}

This experimental laboratory study was done in the cell culture laboratory of Razi Herbal Medicine Research Center at Lorestan University of Medical Sciences in Khorramabad. C. zeylanicum was confirmed by a botanist from Agriculture and Jahad Organization. 

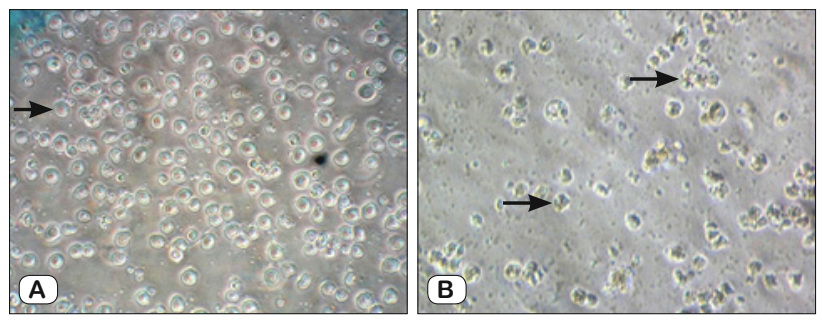

Fig. 1. The intact cells of control sample (A) and apoptotic cells evaluated using reverse phase microscope (B).these cells incubated in 0.1 $\mathrm{mg} / \mathrm{ml} \mathrm{C}$. zeylanicum solution for 24 hours (x100). Fig. A, arrow shows the intact cells. Fig. B, arrows indicate apoptotic cells.

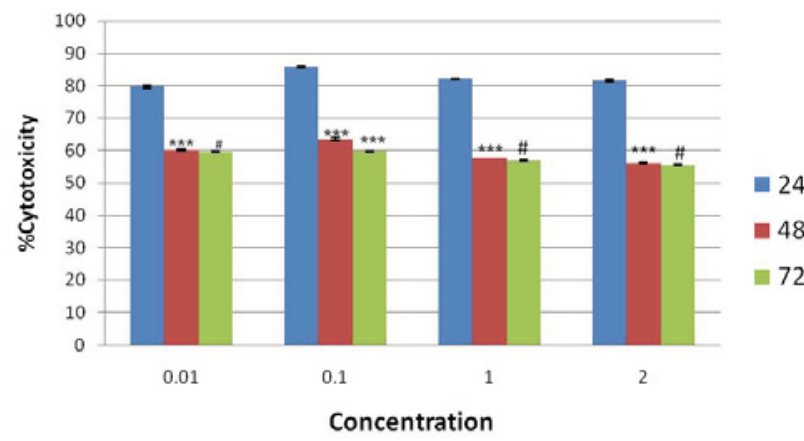

Fig. 2. Cell growth inhibition after the incubation in 2, 1, 0.1, and 0.01 $\mathrm{mg} / \mathrm{ml} \mathrm{C.} \mathrm{zeylanicum} \mathrm{solutions} \mathrm{for} 24,48$, and 72 hours, respectively, using MTT assay.

The C. zeylanicum was ground completely and then it was uniformed by a homogenizer. Afterwards, it was soaked in the distilled water and the aqueous extract was collected. Two, 1, 0.1 and $0.01 \mathrm{mg} / \mathrm{ml}$ solutions were made at the RPMI 1640 medium. These solutions were sterilized by Millipore filtration (pore size: 0.02). These solutions were kept in a refrigerator until the usage.

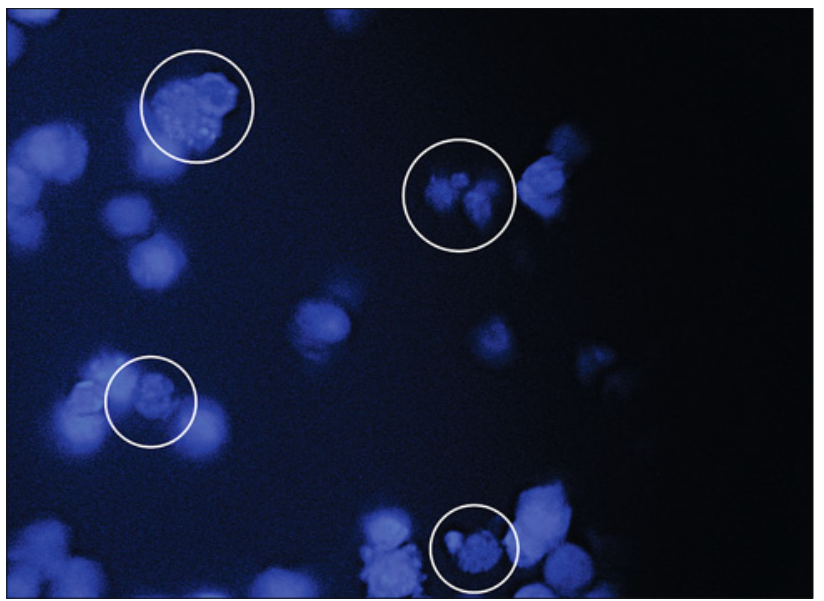

Fig. 4. Incubated cells in $0.1 \mathrm{mg} / \mathrm{ml} \mathrm{C}$. zeylanicum solution for 24 hours using Hoechst 33342 staining and use of fluorescence microscope $(\mathrm{x} 400)$. Apoptotic cells are indicated in the figure by drawing circles around them.

Human myelocytic leukemia cell line (THP-1) was prepared from Pasteur Institute of Iran. The cells were incubated at $37^{\circ} \mathrm{C}$ in the incubator (Memmert, Germany) with $5 \% \mathrm{CO}_{2}$ and $90 \%$ humidity, in the T25 flasks (NUNC, Denmark) and in the RPMI 1640 medium (Gibco, Germany) supplemented with $10 \%$ fetal calf serum (FCS), $100 \mathrm{mg} / \mathrm{ml}$ streptomycin and $100 \mathrm{U} / \mathrm{ml}$ penicillin (Cinnagen, Iran).

THP-1 cells were incubated in 2, 1, 0.1 and $0.01 \mathrm{mg} / \mathrm{ml} \mathrm{C.}$ zeylanicum solutions for 24,48 and 72 hours. The medium was used without cells as blank and the medium with cells and without C. zeylanicum solutions as the control.

Cell proliferation was assessed by the MTT [3-(4, 5- dimethylthiazol-2-yl)-2, 5-diphenyl tetrazolium bromide] assay. THP-1
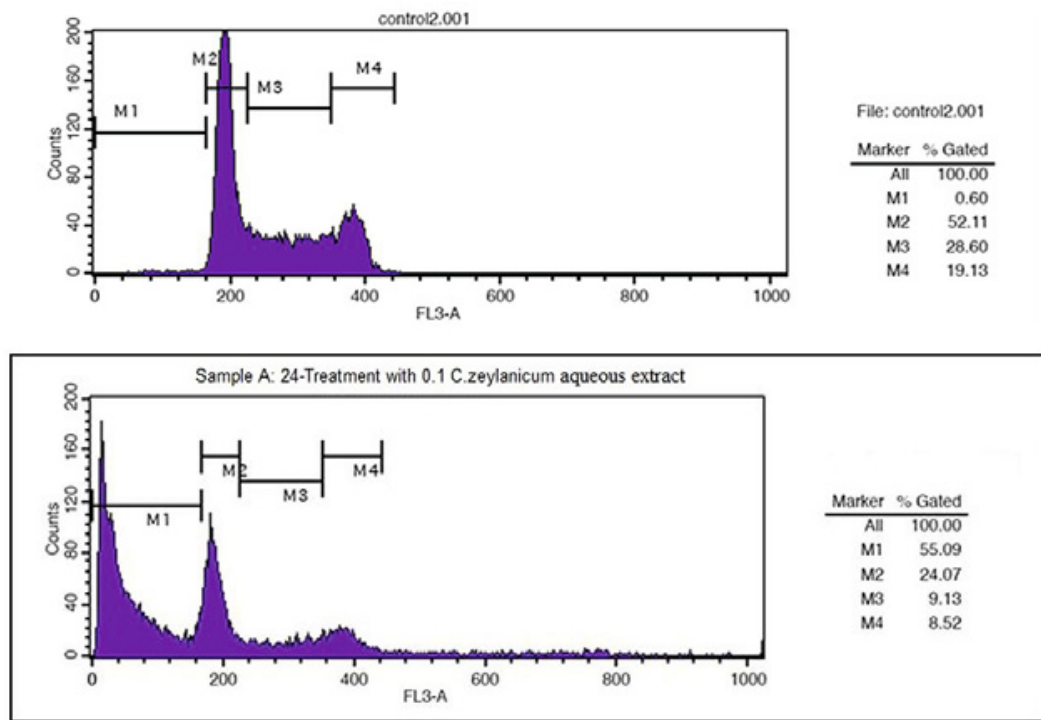

Fig. 3. The distribution of cells in cell cycle phases in THP-1 cells using flow cytometry analysis in the cells of the control samples (the above graph) and cells after 24 hours of incubation in $0.1 \mathrm{mg} / \mathrm{ml} \mathrm{C}$. zeylanicum solution (the below graph). These graphs was applied with Winmdi2.8 software. 
cells were plated at $10^{4}$ cells/well on 96-well plates. At 24, 48 and 72 hours after transfection, $20 \mathrm{ml}$ of MTT $(5 \mathrm{mg} / \mathrm{ml})$ was added to each well; the samples were incubated for 4 hour at $37^{\circ} \mathrm{C}$ and then subculture to the medium with 200 microliter acidic isopropanol. The absorbance of each well was determined at $570 \mathrm{~nm}$. Survival percentage (\%) was calculated relative to the control. The percentage of growth inhibition was calculated by this formula (14): 100 [1- (OD test/ OD control)]

The cell cycle was assessed with flow cytometry (Partec, Germany). The cells were centrifuged at $800 \mathrm{~g}$. Cells were washed with cold phosphate buffered saline (PBS) and were fixed by ethanol $70 \%$. For the evaluation of the cell cycle phases, the cells were mixed with 1 microgram propidium iodide (in $1 \mathrm{ml}$ PBS) and 25 mg RNase A (in $1 \mathrm{ml}$ PBS) for 30 minutes and then assessed by flow cytometry (11).

Apoptotic cells were identified by Hoechst 33342 staining and the use of fluorescence microscope. Two million THP-1 cells were counted using neobar glasses and then were separated. They were incubated in $0.1 \mathrm{mg} / \mathrm{ml}$ of aqueous extract of C. zeylanicum for 24 hours, respectively. The vital cells were used as the control. Afterward, 25 microliter of treated cell suspension and the control sample were mixed with 1 microliter of Hoechst stain (10 microgram $/ \mathrm{ml}$ ). Then, 10 microliters of this mixture were infused on a clean glass and at least 200 cells were evaluated by fluorescence microscope.

\section{Statistical analysis}

The data were analyzed using the SPSS software (V. 18), descriptive statistics, and analytical tests (ANOVA and Tukey tests). $\mathrm{p}<0.05$ were considered statistically significant.

\section{Results}

In the evaluation using the reverse phase microscope, in the incubated cell in $0.1 \mathrm{mg} / \mathrm{ml} \mathrm{C}$. zeylanicum solution for 24 hours, the wrinkled cells were seen and the number of the cells was lower than that in the control sample (Fig. 1).

The results of THP-1 cells incubation in 2, 1, 0.1 and 0.01 $\mathrm{mg} / \mathrm{ml} \mathrm{C}$. zeylanicum solutions for 24, 48 and 72 hours by MTT assay are shown in Figure 2. The difference between cell growth inhibition after 72 and 48 hours of incubation in $0.01 \mathrm{mg} / \mathrm{ml} \mathrm{C.}$ zeylanicum solutions was not significant ( $p>0.05$ ), but the difference between cell growth inhibition after 48 and 24 hours of incubation was significant $(\mathrm{p}<0.001)$. The difference between cell growth inhibition after 72 and 48 hours and between 48 and 24 hours of incubation in $0.1 \mathrm{mg} / \mathrm{ml} \mathrm{C}$. zeylanicum solutions was significant $(\mathrm{p}<0.001)$. The difference between cell growth inhibition after 72 and 48 hours of incubation in $1 \mathrm{mg} / \mathrm{ml} \mathrm{C}$. zeylanicum solutions was not significant ( $p>0.05$ ), but the difference between cell growth inhibition after 48 and 24 hours of incubation was significant $(\mathrm{p}<0.001)$. The difference between cell growth inhibition after 72 and 48 hours of incubation in $2 \mathrm{mg} / \mathrm{ml} \mathrm{C}$. zeylanicum solutions was not significant $(\mathrm{p}>0.05)$, but the difference between cell growth inhibition after 48 and 24 hours of incubation was significant $(\mathrm{p}<0.001)$.
The results of flow cytometry analysis are shown in Figure 3. In the control sample, $0.6 \%$ of the cells were in sub-G1 phase. Also, after 24 hours of incubation in $0.1 \mathrm{mg} / \mathrm{ml} \mathrm{C}$. zeylanicum solution, $55.09 \%$ of the cells were in sub-G1 phase. Based on flow cytometry analysis, the amount of cells in apoptosis phase after 24 hours of incubation in $0.1 \mathrm{mg} / \mathrm{ml}$ was more than the other groups of study.

The amount of cells in apoptosis phase detected by Hoechst 33342 staining and the use of fluorescence microscope after 24 hours of incubation in $0.1 \mathrm{mg} / \mathrm{ml} \mathrm{C}$. zeylanicum solutions was higher than the other groups of study (Fig. 4).

\section{Discussion}

C. zeylanicum is an ancient medicinal plant. The effects of C. zeylanicum are due to the effects of its components. Gursale et al., evaluated the Cinnamomum zeylanicum Blume extracts by reversed-phase high performance liquid chromatographic method (15). Gursale et al. reported that Cinnamaldehyde was the major component of Cinnamomum zeylanicum Blume (15). Also, Unlu et al., evaluated the essential oil of C. zeylanicum Blume bark by GC-MS (16). Unlu et al reported that (E)-cinnamaldehyde, benzaldehyde and (E)-cinnamyl acetate were the main components of the essential oil (16). On the other hand, Ka et al stated that Cinnamaldehyde was a component of Cinnamomum cassia stem bark (17).

The results of our study showed that $\mathrm{C}$. zeylanicum aqueous extract induced apoptosis in the human myelocytic leukemia cell lines. In our study, incubation in $0.1 \mathrm{mg} / \mathrm{ml} \mathrm{C}$. zeylanicum solution compared to 2, 1 and $0.01 \mathrm{mg} / \mathrm{ml} \mathrm{C}$. zeylanicum solutions had more effects on THP-1 cells. Also, in our study, according to flow cytometry analysis after 24 of incubation in $0.1 \mathrm{mg} / \mathrm{ml} \mathrm{C}$. zeylanicum solutions, the amount of cells in apoptotic phase was higher than in the control sample.

Our findings are in according with Schoene et al's study (11). Schoene et al assessed the effect of cinnamon water-soluble fraction on lymphoma and leukemic cell lines. Schoene et al. declared that cinnamon water-soluble fraction decreased cellular growth in a lymphoma and two leukemic cell lines. However, Schoene et al. reported that the block occurred in G2/M phase.

As mentioned above, Cinnamaldehyde is a component of some kind of cinnamon. Ka et al reported that Cinnamaldehyde can induce the apoptosis (17). Also, Ng and Wu assessed the antiproliferative activity of cinnamaldehyde, cinnamic acid and cinnamyl alcohol on human hepatoma Hep G2 cells. Ng and Wu reported that, compared with cinnamic acid and cinnamyl alcohol, cinnamaldehyde had more antiproliferative activity (18). Zhang et al reported that trans-cinnamaldehyde had cytotoxic activity on human leukemia K562 cells (19). Zhang et al., reported that apoptosis was one of the causes of cytotoxic effects of trans-cinnamaldehyde (19). Furthermore, Lee et al., evaluated the anti-tumor effects of several cinnamaldehyde derivatives on SW620 human colon cancer cells. They stated that some cinnamaldehyde derivatives caused inhibition of AP-1 transcriptional activity in these cells (20). Finally, it is proposed to investigate more closely the effects of cinnamon on cancer cells, this study was conducted on laboratory animal cancer models. 


\section{Conclusion}

The results of our study showed that C. zeylanicum aqueous extract induced apoptosis in the human myelocytic leukemia cell line. Obviously, this effect is due to the effects of the C. zeylanicum components.

\section{References}

1. Lau CBS, Ho CY, Kim CF, Leung KN, Fung KP, Tse TF, Chan HHL, Chow MSS. Cytotoxic activities of Coriolus versicolor (Yunzhi) extract on human Leukemia and lymphoma cells by induction of apoptosis. Life Sciences 2004; 75: 797-808.

2. Jeffrey E, Gibson B, Franklin O. Acute Myeloid Leukemia. Pediatr Clin N Am 2008; 55: 21-51.

3. Brandts C, Berdel W, Serve H. Oncogenic Signaling in Acute Myeloid Leukemia. Current Drug Targets 2007; 8: 237-246.

4. Elliott P, Wakefield J, Best N, Briggs D. Spatial epidemiology methods and applications. New York: Oxford University Press, 2007.

5. Hwang JS. AIP1, a Water-Soluble Fraction from Artemisia iwayomogi, suppresses thymocyte apoptosis in vitro and down-regulates the expression of fas gene. Biol Pharm Bull 2005; 28: 921-924.

6. Faix S, Faixová Z, Plachá I, Koppel J. Effect of Cinnamomum zeylanicum Essential Oil on Antioxidative Status in Broiler Chickens. ACTA VET. BRNO 2009; 78: 411-417.

7. Ranasinghe P, Perera S, Gunatilake M, Abeywardene E, Gunapala N, Premakumara S, Perera K, Lokuhetty D, Katulanda P. Effects of Cinnamomum zeylanicum (Ceylon cinnamon) on blood glucose and lipids in a diabetic and healthy rat model. Pharmacognosy Res 2012; 4: 73-79.

8. Murcia MA, Egea I, Romojaro F, Parras P, Jiménez AM, MartínezTomé M. Antioxidant evaluation in dessert spices compared with common food additives. Influence of irradiation procedure. J Agric Food Chem 2004; 52: 1872-1881.

9. Brahmachari S, Jana A, Pahan K. Sodium benzoate, a metabolite of cinnamon and a food additive, reduces microglial and astroglial inflammatory responses. J Immunol 2009; 183: 5917-5927.

10. Khan A, Safdar M, Khan M, Khattak K, Anderson R. Cinnamon improves glucose and lipids of people with type 2 diabetes. Diabet Care 2003; 26: 3215-3218.
11. Schoene N, Kelly M, Polansky M, Anderson R. Water-soluble polymeric polyphenols from cinnamon inhibit proliferation and alter cell cycle distribution patterns of hematologic tumor cell lines. Cancer Lett 2005; 230: $134-140$.

12. Koppikar S, Choudhari A, Suryavanshi S, Kumari Sh, Chattopadhyay S, Kaul-Ghanekar R. Aqueous Cinnamon Extract (ACE-c) from the bark of Cinnamomum cassia causes apoptosis in human cervical cancer cell line (SiHa) through loss of mitochondrial membrane potential. BMC Cancer2010; 10: 2-12.

13. Assadollahi V, Parivar K, Hayati Roudbari N, Khalatbary A, Motamedi M, Ezatpour B, Dashti G. The effect of aqueous cinnamon extract on the apoptotic process in acute myeloid leukemia HL-60 cells. Adv Biomed Res 2013; 2: 25.

14. Sundartan S, Milner J. Impact of organs compounds in garlic on canine mammary tumor cells in cultures. Cancer Lett 1993; 174: 85-90.

15. Gursale A, Dighe V, Parekh G. Simultaneous quantitative determination of cinnamaldehyde and methyl eugenol from stem bark of Cinnamomum zeylanicum Blume using RP-HPLC. J Chromatogr Sci 2010; 48: 59-62.

16. Unlu M, Ergene E, Unlu G, Zeytinoglu H, Vural N. Composition, antimicrobial activity and in vitro cytotoxicity of essential oil from Cinnamomum zeylanicum Blume (Lauraceae). Food Chem Toxicol 2010; 48: 3274-3280.

17. Ka H, Park H, Jung H, Choi J, Cho K, Ha J, Lee K. Cinnamaldehyde induces apoptosis by ROS-mediated mitochondrial permeability transition in human promyelocytic leukemia HL-60 cells. Cancer Lett 2003; 196: 143-152.

18. Ng L, Wu S. Antiproliferative Activity of Cinnamomum cassia Constituents and Effects of Pifithrin-Alpha on Their Apoptotic Signaling Pathways in Hep G2 Cells. Evid Based Complement Alternat Med 2011; 1-6.

19. Zhang J, Liu L, He Y, Kong W, Huang S. Cytotoxic effect of transcinnamaldehyde on human leukemia K562 cells. Acta Pharmacol Sin 2010; 31: 861-866.

20. Lee C, Lee S, Lee J, Ban J, Lee S, Yoo H, Jung J, Moon D, Oh K, Hong J. 2-hydroxycinnamaldehyde inhibits SW620 colon cancer cell growth through AP-1 inactivation. J Pharmacol Sci 2007; 104: 19-28.

Received August 29, 2013. Accepted September 19, 2013. 